\title{
«Vi rigger til så godt vi kan» - konturer av praksisarkitekturer som muliggjør og hindrer undervisning $i$ materialet tre $i$ kunst- og håndverksfaget $i$ norsk barneskole
}

\author{
Pauliina Maapalo*, \\ Nord Universitet, PHS Enhet for leererutd. og kulturfag, 8700 Nesna, Norge
}

\begin{abstract}
Sammendrag
I denne artikkelen undersøkes og tegnes konturene av byggeklossene til praksisarkitekturer som muliggjør og hindrer undervisning i materialet tre i kunst- og håndverksfaget i den norske barneskolen. Undersøkelsens fokus, trearbeidspraksiser i barneskoler, er motivert av forfatterens egne erfaringer fra lærerutdannerpraksiser og «rop fra feltet» som uttrykker en bekymring for at bruken av trematerialer og kompetansen knyttet til disse i den pedagogisk-didaktiske konteksten er svekket. Som analyseverktøy brukes de australske forskerne Stephen Kemmis og Peter Grootenboers praksisteori. Ved hjelp av praksisteorien undersøkes hvordan muligheter og hindringer for arbeid med tre i barneskolen oppstår i et dynamisk samspill mellom praksiser og praktikere (lærere på barneskolen), intersubjektive rom og praksisarkitekturer. I artikkelen fokuseres det særlig på byggeklossene som skaper praksisarkitekturene. Som empirisk materiale kombineres en oversiktsundersøkelse gjennomført ved hjelp av spørreskjemaer besvart av lærere, med en mikroetnografisk tilnærming der praksiser i et utvalg av skoler beskrives og fortolkes mer dyptgående.
\end{abstract}

\section{Nøkkelord: Trearbeid; kunst og håndverk; barnetrinnet; mikroetnografi}

\begin{abstract}
The study presented in this article is connected to the field of arts and crafts teaching and learning in Norwegian primary school and the use of wood as material. Woodwork has had varied focus and status in educational curriculums but it seems as if this status has gradually faded. The purpose of this article is to sketch the contours of woodwork practices throughout three counties, Nordland, Nord-Trøndelag and Sør-Trøndelag using a large survey and a micro ethnographic study in eight primary schools. The empirical material of the study is analysed using the theory of practice architectures as lenses. The aim of the analysis is to identify the building blocks that enable and constrain woodworking practices in Norwegian primary schools.
\end{abstract}

${ }^{\star}$ Korrespondanse to: Pauliina Maapalo, Nord Universitet, 8700 Nesna, Norge. Email: pauliina. maapalo@nord.no 
Keywords: Arts and crafts teaching and learning; wooden material; micro ethnography; primary school education

Received: August 2016; Accepted: October 2016; Published: January 2017

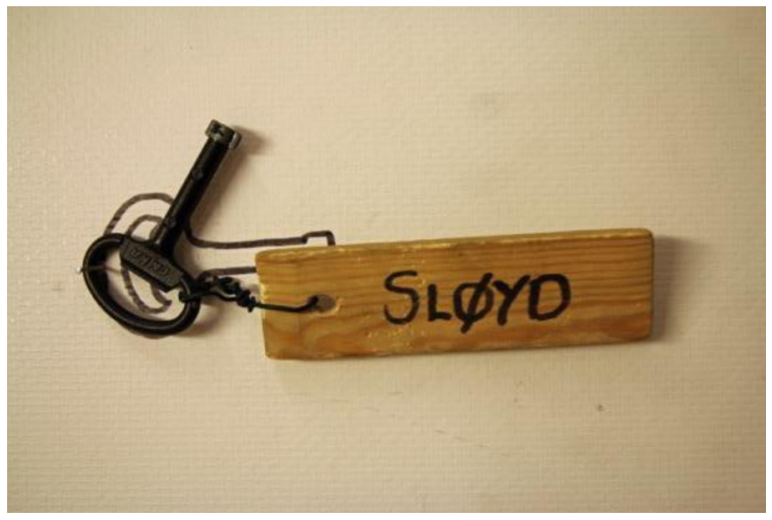

\section{Innledning - forfatterstemme og motivasjon for undersøkelsen}

Hele mitt doktorgradsarbeid innenfor feltet kunst og håndverksdidaktikk, som denne artikkelen er en del av, er et forsøk på å svare på «rop fra feltet» - rop som i sin korthet handler om at tilstanden for trearbeid og håndverk i skolen og generelt $\mathrm{i}$ samfunnet er svekket (f.eks. Berntsen, 2014; Hansen, 2015; Høiby, 2014; Iversen, 2016; Knudsen, 2015; Sandvik, 2015). I mitt arbeid som lærerutdanner med stor personlig interesse for trematerialer, har jeg de siste årene opplevd et tap av kompetanse knyttet til trematerialer blant lærerstudenter og på praksisfeltet. Dette har skjedd $i$ en tid der faget kunst og håndverk $i$ sin helhet er blitt fjernet som et obligatorisk fag i lærerutdanning for trinnene 1-7. Situasjonen illustreres ved at hele $90 \%$ av lærerstudentene ved Universitetet i Tromsø ikke har annen kompetanse i kunst og håndverk enn egen grunnskole når de begynner som lærere på barnetrinnet (Opstad, 2013, s. 23). Fokuset på materialet tre i barneskolen ser ut til å være betraktelig nedtonet fra «tresløydens tid».

Tre som materiale nevnes nå i læreplanen $\mathrm{i}$ faget kunst og håndverk kun under kompetansemål i design etter 4. årstrinn: «eleven skal kunne bruke enkle, hensiktsmessige håndverktøy i arbeid med leire, tekstil, skinn og tre» (Utdanningsdirektoratet, 2006, s. 6). Det er bekymringen for trearbeidets tilstand og nysgjerrigheten i forhold til det som faktisk skjer i trearbeidspraksiser i skolen, som fikk meg til å legge ut på denne forskningsreisen.

I min studie ønsker jeg å bidra med å gi en stemme til og øke forståelsen for håndverk med tre som materiale $\mathrm{i}$ grunnskolen. Jeg har vært på skolebesøk ved til sammen åtte skoler som tilhører studiens målgruppe (alle barneskolene ved fylkene Nordland, Nord-Trøndelag og Sør-Trøndelag), og fått muligheten til å observere arbeid med tre på barnetrinnet, samt hatt intervjusamtaler med lærerne. 
Følgende forskningsspørsmål leder meg i analysen i artikkelen: Hvordan kan konturene av byggeklosser $i$ praksisarkitekturer for arbeid med materialet tre $i$ barneskolen tegnes opp og kritisk diskuteres gjennom analyse av et empirisk materiale bestående av spørreundersøkelse og skolebesøk?

\section{Plassering i forskningsfeltet}

For å skissere forskningskonteksten vil jeg først avklare sentral begrepsbruk og den pedagogisk-didaktiske særstillingen for arbeid med tre i kunst- og håndverksfaget som Norge har i Norden. Jeg vil i denne artikkelen bruke hovedsakelig betegnelsen trearbeid om praksiser som jeg har studert og betegnelsen sløyd når jeg henviser til trearbeid i en nordisk sløydfaglig forskningskontekst og til datamateriale som ligger tett opp til lærernes bruk av begrepet. I land som Finland (Utbildningsstyrelsen, 2014) og Sverige (Skolverket, 2011) inneholder sløyd flere materialområder, mens i den norske bruken av begrepet sløyd er det hovedsakelig tre som framstår som materialet som skal bearbeides, slik at sløyd er nærmest synonymt med begrepet tresløyd, noe som kommer fram i eldre læreplaner og lærebøker (Kjosavik 2001; Thorsnes, 2012).

I konteksten for denne artikkelen er det ikke mulig for meg å gå dypere inn i mangfoldet av forskning knyttet til selve sløydprosesser. Kort sagt handler sløyd og sløydrelatert arbeid (som kunst og håndverk) om læringssituasjoner der elever i møte med materialer, verktøy og redskaper og i sosial interaksjon omformer materialer til artefakter (Johansson, 2002, s. 205-206). I en sløydprosess er dermed både materielle og immaterielle aspekter i et samspill, fra råvarer og verktøy (det materielle) til for eksempel kunnskap, handlingsberedskap og tid (det immaterielle) (Johansson, 1998, 2002, s. 20).

I de nordiske landene er det lange tradisjoner for forskning innen sløyd (Mäkelä, 2011 , s. 25), men med noen vesentlige skiller i fag- og forskningstradisjoner blant landene. I Finland og Sverige er for eksempel sløyd og bildkonst (i Sverige slöjd og bild) to separate fag (Utbildningsstyrelsen, 2014; Skolverket, 2011) i grunnskolen. I Finland forankres sløyd i vitenskapsdisiplinene sløydvitenskapen og sløydpedagogikken (Lindfors, 1999; Peltonen, 1999) og i Sverige i pedagogiken og pedagogisk arbete samt andre «utbildningsvetenskapliga paraplyområden» (Mäkelä, 2011, s.18). Det norske skolefaget kunst og håndverk skiller seg ut fordi Norge er det eneste landet som har koblet sammen bilde-/kunsttradisjonen og sløyd-/håndverkstradisjonen til et grunnskolefag (Brænne, 2011, s. 95). Kunst- og håndverksfaglig forskning støtter seg til forskningsdisiplinen the making-diciplines som omfatter blant annet designdidaktikk og produksjon av artefakter (Dunin-Woyseth \& Michl, 2001; Fauske, 2016, s. 51; Nielsen, 2008). I de nordiske landene generelt finnes det mye forskning knyttet til sløydpedagogiske/didaktiske problemstillinger. ${ }^{1}$

Det ser ut til å finnes lite forskning knyttet til bruken av trematerialer i den norske grunnskolen, spesielt med fokus på trinnene 1-7. Undersøkelsene der forhold rundt

\footnotetext{
${ }^{1}$ Eksempler på sløyd- og sløydrelatert forskning i Norden og Norge er Autio, 1997; Borg, 2001; Brænne, 2009; Digranes, 2009; Frohagen, 2016; Gulliksen, 2006; Hartvik, 2013; Hilmola, 2012; Illum, 2004; Kjosavik, 1998; Lutnæs, 2011; Nygren-Landgärds, 2000.
} 


\section{Pauliina Maapalo}

trearbeid i norsk kontekst blir belyst, er først og fremst store kvantitative kartleggingsundersøkelser, som Skolefagsundersøkelsen 2011 (Espeland et al., 2013) der blant annet den lave kompetansen blant barneskolelærere innen kunst og håndverk, og de trange rammebetingelsene for verkstedsundervisning innen materialet tre, blir belyst. Sømoe (2013, s. 1) konkluderer med at kunst og håndverk, etter hans forståelse, best kan beskrives som et tverrfaglig felt, "snarere enn et fag i vitenskapsfaglig betydning». Gjennom min studie blir funn i Skolefagsundersøkelsen 2011 (Espeland et al., 2013) bekreftet, styrket og supplert.

\section{Teorien om praksisarkitekturer}

Teorien om praksisarkitekturer er utviklet av de australske forskerne Kemmis og Grootenboer (2008) i en dynamisk prosess der de selv har forsket på praksiser. De er opptatt av revitaliseringen av utdanning på en måte som ikke bare skjer på et abstrakt og generelt nivå, men på alle de konkrete stedene der utdanningspraksiser faktisk foregår (Kemmis et al., 2014, s. 12). Kemmis et al.'s teori om praksisarkitekturer handler om hvordan praksiser er komponert og hvordan de muliggiøres gjennom ulike forhold som holder dem på plass (Kemmis et al., 2014, s. 11). Teorien er nyttig når man skal forstå eller forandre komplekse praksiser og identifisere aspekter som hindrer eller muliggiør disse (Kemmis et al., 2014, s. 7), og dette giør teorien relevant for denne studien. Praktikere som inngår i praksiser, møtes i intersubjektive rom som består av ulike forhold. Bakgrunnsbildet er en rein illustrasjon og henviser til materialet som er sentral i studien.

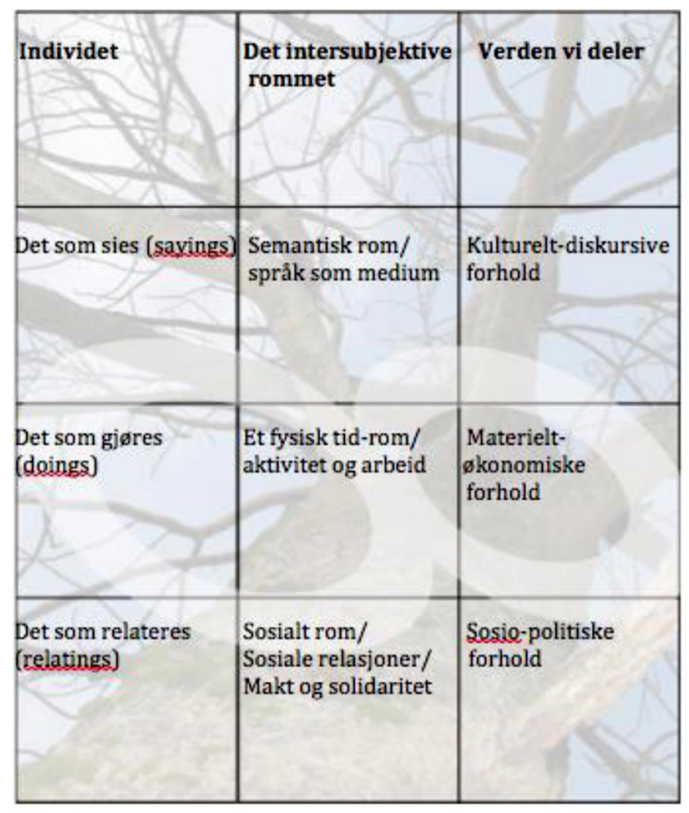

Figur 1. Modell av praksisarkitekturer (Kemmis et al., 2014), oversatt og modifisert av Pauliina Maapalo. 
Den venstre siden av modellen (figur 1) viser hvordan praksisene bekreftes interaksjonelt gjennom hva man sier og tenker (sayings), hva man gjør (doings) og hvordan man forholder seg (relatings). Prosessen som handler om å bli initiert til en praksis, er avhengig av praksisarkitekturer (til høyre i modellen) som hindrer eller muliggjør dette (Kemmis et al., 2014, s. 38):

a) Kulturelt-diskursive forhold $\mathrm{i}$ et semantisk rom (semantic space $\mathrm{i}$ midten av modellen) med språk som medium.

b) Materielt-økonomiske forhold i den fysiske dimensjonen av tid og rom (in physical-time/space i midten av modellen), gjennom aktivitet og arbeid.

c) Sosio-politiske forhold i et sosialt rom (in social space i midten av modellen) som handler om sosiale relasjoner, makt og solidaritet.

Muligheter og begrensninger i en praksis skapes i intersubjektive samspill mellom disse ulike forholdene. I analysen i denne studien «leser» jeg altså datamateriale med teorien om praksisarkitekturer som et analytisk verktøy eller linse, samt «kobler på» andre stemmer som Eriksens (2015a; 2015b) filosofiske diskusjoner rundt begreper som integritet og dedikasjon. Kemmis et al. har brukt en noe tilsvarende tilnærming som de kaller «philosophical-empirical inquiry» (2014, s. 21) i sin teoriutvikling. Teorien om praksisarkitekturer blir beskrevet mer dyptgående samtidig som jeg gjør selve analysen. Teorien har vært en god samtalepartner som har gitt meg muligheten til å lese et komplekst materiale i forhold til «det som sies, gjøres og relateres» i de ulike «rommene» (Kemmis et al., 2014). Denne samtalen mellom praksisteorien og mitt empiriske materiale har hjulpet meg til å se hvordan ulike aspekter i praksiser interagerer og påvirker hverandre. Gradvis har jeg klart å konstruere og navngi de byggeklossene som ser ut til å skape praksisarkitekturene i de spesifikke trearbeidspraksisene jeg har undersøkt.

\section{Metodologi, posisjonering og empiri}

Studiens empirigenerering består av en surveyundersøkelse, som også fungerte som en invitasjon til studiens andre del, skolebesøk. Jeg benytter meg av etnografisk metodologi med en mikroetnografisk (Postholm, 2010, s. 48) tilnærming som innbefatter kortere opphold i felt enn ved konvensjonelle etnografiske studier. Den vitenskapsfilosofiske posisjoneringen er posthumanistisk og nymaterialistisk (Bennett, 2010; Braidotti, 2013; Deleuze \& Guattari, 2013). I korthet betyr dette at mennesket forskyves noe ut av sentrum, og isteden forstås som en del av naturen, strukturer og systemer. Videre forstås de materialer som mennesket omgir seg med og interagerer med (som materialet tre), som at de har agency (se for eksempel Bennett, 2010, s. 9). Materialene, som tre, «inviterer» til gitte handlinger og interaksjoner og kan ses på som aktive aktanter (actants) - et begrep som er kjent fra Latours utvikling av actor-network theory (ANT), en sosial teori som inkluderer «humans» og «non-humans» på en likeverdig måte (Latour, 1996, s. 2; 2004, s. 76-77 og s. 237; 2005). «-an actant-, that is, 


\section{Pauliina Maapalo}

something that acts or to which activity is granted by others.» (Latour, 1996, s. 7). Jeg forstår materialet tre som en aktant som inviterer til aktivitet i denne studien.

\section{Surveyundersøkelsen og utvalg til skolebesøkene}

Surveyundersøkelsen gjennomførte jeg i form av en spørreundersøkelse rettet mot lærere som underviser i faget kunst og håndverk i barneskolen, noe som viste seg å være en komplisert prosess som jeg ikke har mulighet til å gå nærmere inn på her. Til sammen sendte jeg over 400 forespørsler til e-postadressene til alle kommunale barneskoler i fylkene Nordland, Nord-Trøndelag og Sør-Trøndelag, og fikk til slutt 182 svar på spørreundersøkelsen. I spørreundersøkelsen spurte jeg også om muligheten for at jeg kunne komme på skolebesøk og fikk ca. 20 positive svar på dette, hvorav åtte lot seg gjennomføre innen den gitte tidsrammen. Når det gjelder surveyundersøkelsen, vil jeg i denne artikkelen, på grunn av plassbegrensning, kun se nærmere på svar fra spørreundersøkelsen som handler om kompetanse samt noen svar som surveydeltakerne skrev i feltet «frie kommentarer».

\section{Skolebesøk og datagenerering gjennom flersanselige samtaler}

De åtte skolebesøkene varierte i lengde, fra to timer til en hel arbeidsdag for læreren. Datagenereringen besto av observasjon, semi-strukturert intervju, fotodokumentasjon og video- og lydopptak. I skolene har jeg i forskerrollen fokusert på å være fullstendig i øyeblikket, noe som har vært en krevende oppgave. På de fleste stedene fant jeg meg en stol i et hjørne som et slags forankringspunkt, men det meste av tiden gikk jeg rundt i rommene for å skape kontakt med elevene og for å fotografere arbeidene deres. Disse besøkene kan best beskrives som sanselige eksplosjoner der banke-, sage- og borelyder i perioder var så øredøvende at vanlig tale ikke var mulig, og der fint trestøv tettet øynene og nektet pennen min å gi fra seg blekk på observasjonsnotatarkene. Til tross for den korte varigheten skolebesøkene hadde, har de sanselige inntrykkene jeg har fått, vært rike og viktige når det gjelder å få en følelse av kvalitetene ved de ulike stedene. Over alt har materialiteter, kropper og strukturer hatt agency (Bennett, 2010, s. 9) og sterk påvirkning i tillegg til det som sies. At samtalene med lærerne i de fleste tilfeller fant sted på trearbeidsrommene, er en del av strategien der jeg legger vekt på det jeg kaller flersanselige samtaler. Det innebærer at jeg har vært opptatt av å «vekke» lærernes kroppslige hukommelse ved at flere sanser aktiveres i samtalene. Jeg har tidligere erfart hvor rike samtalene blir når de fysiske omgivelsene eller fysiske «tingene» man snakker om, er til stede og gir muligheten til sanselig utforskning. Den mikroetnografiske tilnærmingen jeg bruker, er knyttet til sensory ethnography (Pink, 2015, s. 28) der «the experiencing, knowing and emplaced body» er den sentrale ideen. Fotografier fra skolebesøk har også en sentral funksjon for min analytiske prosess. Jeg bruker bilder som hukommelsesredskaper i analyse- og tolkningsarbeidet og som kvalitets-/ troverdighetskriterier for hele studien.

\section{Kort presentasjon av lærerne og skolene}

For å navngi og samtidig anonymisere de åtte ulike praksiser jeg fikk et nærmere innblikk i, bruker jeg oppdiktede navn på lærerne: Pål, Mona, Ellen, Aina, Kristin, 
Terje, Ingvild og Laila. Skolene jeg fikk besøke varierte i størrelse, skoleklasser, i barns alder og antall elever. Fem av lærerne arbeidet i relativt store byskoler med ca. 300-500 elever og tre av lærerne i småskoler, fådelte skoler, langt fra bysentre med bare syv elever i den minste gruppen.

Lærerne jeg møtte på skolebesøkene, hadde samlet sett en høyere gjennomsnittlig formell kompetanse (75 studiepoeng (stp)) innen kunst og håndverk enn det som er gjennomsnittet for alle lærere i surveyundersøkelsen (45 stp, gjelder målgruppen i studien; lærere som underviser i trematerialer, se neste avsnitt) men variasjonen blant dem er stor (fra 0 til 210 stp). Den formelle kompetansen som er spesifikt knyttet til trearbeid, er ikke særlig stor. Samtidig virker den uformelle kompetansen som kommer til uttrykk som interesse og egne erfaringer, som det som muliggiør undervisningen i trearbeid hos noen av lærerne i denne gruppen.

\section{Analyse - å skrive fram byggeklosser i en praksisarkitektur}

Når jeg analyserer fram ulike byggeklosser og skaper konturer av praksisarkitekturer for trearbeid i grunnskolen, gjør jeg det på tvers av surveyundersøkelsen og skolebesøkene. Jeg bruker de ulike byggeklossene jeg analyserer fram som undertitler i analysen som følger. Disse er kompetanse, rom og materialitet, integritet, elevengasjement og larerdedikasjon $i$ samspill og tradisjon. Byggeklossene danner ikke binære kategorier i forhold til hva som hindrer eller muliggjør trearbeidspraksiser. Det er heller slik at hver byggekloss inneholder spenninger som kommer til syne $i$ analysen.

\section{Kompetanse som byggekloss}

Lærernes formelle samt uformelle kompetanse og utdanning innen faget kunst og håndverk kan diskuteres i lys av de sosio-politiske forhold innen praksisarkitekturer som realiseres gjennom makt og solidaritet i dimensjonen "social space» (Kemmis et al., 2014, s. 31-32). Dette aspektet kan blant annet handle om påkrevd kompetanse for å undervise i forskjellige fag.

\section{Formell kompetanse}

Den gjennomsnittlige kompetansen i kunst og håndverk blant lærere som underviser innen trematerialer i denne studien $(\mathrm{N}=110)$, er 45 stp. Det er 28 lærere som har null studiepoeng i faget. Over $60 \%$ av disse har 30 eller mindre stp innen kunst og håndverk. Dette samstemmer godt med funn fra Skolefagsundersøkelsen 2011 (Espeland et al., 2013) der den generelt lave kompetansen innen faget kommer fram.

Når det gjelder lærernes formelle kompetanse knyttet til materialet tre, avga hele 41 (av 110) respondenter ingen svar. Dette kan tolkes som om respondentene ikke kan svare på spørsmålet fordi de ikke husker eller sliter med å tolke spørsmålet, eller fordi faget kan ses på som et tverrfaglig felt (Sømoe, 2013, s. 1). Over halvparten av lærerne har ingen formell kompetanse innen materialet tre, og det er bare noen få 
respondenter med særdeles mye formell kompetanse innen materialområdet (to med $60 \mathrm{stp}$, en med 75 og en med 90).

Gjennomsnittlig underviser lærerne kun 35 timer $\mathrm{i}$ året innen trematerialer. Det er stor spredning på lærernes undervisningstimer, ti underviser fem timer eller mindre og ni underviser over 100 timer (fra 100 til 200).

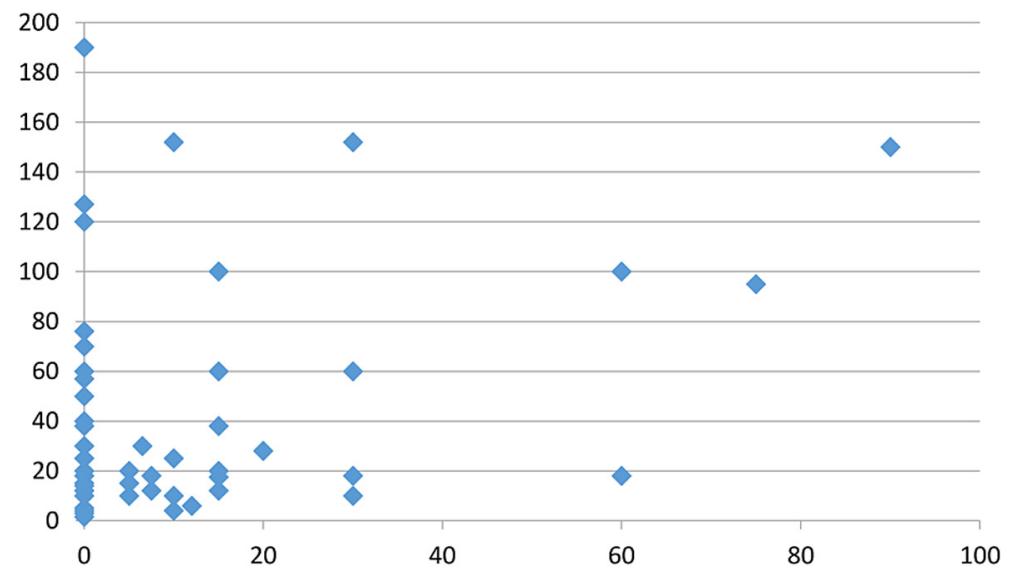

Figur 2. Formell kompetanse i tre (studiepoeng) sett i forhold til undervisningstimer i materialet tre/år blant lærerne med formell kompetanse i kunst og håndverk i studien. Formell kompetanse (studiepoeng) på x-aksen, antall undervisningstimer på y-aksen. (Antall svar: 60. 50 av 110 respondenter har ikke svart eller har avgitt for utydelig svar.)

Grafen (figur 2) viser sammenhengen mellom formell kompetanse i tre sett i forhold til antall undervisningstimer i trematerialer $\mathrm{i}$ året. Man kan se at de fleste lærerne med lite kompetanse, som også underviser lite i trematerialer, utgjør den største gruppen lærere. Det er i tillegg noen få lærere med høy kompetanse og mye undervisning i trematerialer (for eksempel en lærer med 90 stp underviser 150 timer). Samtidig er det bemerkelsesverdig at læreren med ingen formell kompetanse underviser aller mest i gruppen (190 timer). Drøyt halvparten av lærerne underviser innen trematerialer uten formell kompetanse.

\section{Uformell kompetanse}

31 av 110 respondenter med formell utdanning i kunst og håndverk (altså 28 \%) gir uttrykk for at de har noen form for uformell kompetanse innen trematerialer. I dette regnestykket har jeg selv operasjonalisert lærernes verbale svar der de uttrykker ulike former for kompetanse som kurs, snekkererfaring/snekkerutdanning og fritidsinteresser. Disse uttrykkes blant annet i følgende utsagn:

Interesse for, og 14 års erfaring med kunst og håndverk $i$ skolen. Har bygget flere egne hus, har vart med og bygget flere trebåter. Og har hatt jobb $i$ betongindustrien. (Lærer uten formell kompetanse innen kunst og håndverk? men som underviser 60 timer $i$ året innen trematerialer.) 
Vi har sett det som viktig på skolen å «plassere» lcerere med formell og uformell kompetanse også $i$ treforming - på faget. (Rektor/lærer, 30 stp i kunst og håndverk? underviser enkelte år.)

Det kan virke som om uformell kompetanse verdsettes i noen skoler, eller at det er den eneste kompetansen man har tilgjengelig noen steder. Samtidig kan det hende at man bruker lærere uten kompetanse i kunst og håndverk eller trematerialer, innen trearbeid, fordi dette ikke verdsettes.

Rom og materialitet som byggekloss

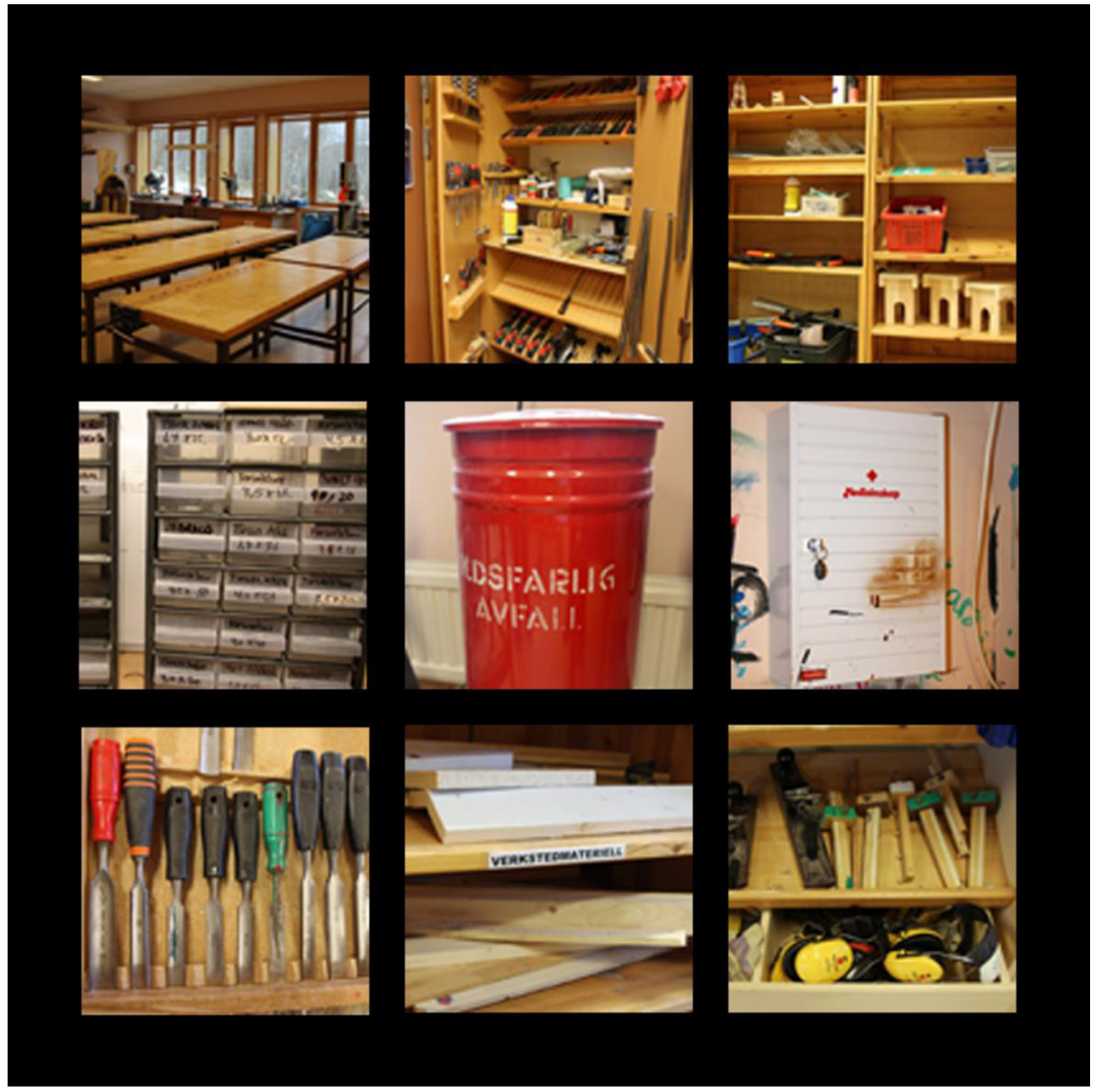

Bildecollage 1. Materialer og rom for trearbeid i barneskolen.

Byggeklossen rom og materialitet blir til i den fysiske dimensionen av tid og rom (Kemmis et al., 2014, s. 4). Slike forhold handler om hva det brukes midler på, hvordan rommene brukes og ser ut, og om fordelingen av menneskelige ressurser og utstyr 


\section{Pauliina Maapalo}

(Østern, 2016, s. 5). Materielle forhold vektlegges som kanskje det mest grunnleggende når man analyserer menneskenes liv. «Basic doings and sayings, for example, are carried out by embodied human beings. Just about every practice, moreover, deals with material entities (including human bodies) that people manipulate or react to» (Schatzki 2012, s. 16).

I det følgende vil jeg ved hjelp av sitater fra intervjuene «reise på raske besøk» til noen av lærerne for å trekke fram eksempler fra romlige forhold, utsagn, situasjoner som på ulike vis enten muliggjør eller hindrer trearbeidspraksiser.

I seks av åtte skoler jeg besøkte, fantes det «innerom» som kommuniserte en eller annen form for trearbeidspraksis. Ved første øyekast var de fleste rommene ganske like: trearbeidsbenker der arbeidsstykker kunne settes fast, ekstra arbeidsbenk og noen mindre maskiner langs veggene, diverse hyller og skap og smårom for oppbevaring av materiale, verktøy, redskap og elevarbeid. Konseptet «rom» bestod av og til av klynger av smårom med ulike funksjoner, som til sammen utgjorde en funksjonell enhet. Forskjeller og ulike aspekter ved rommets betydning kom fram i løpet av de åtte skolebesøkene.

- Ellen - «mye kompetanse som smuldrer opp»

/. . . du møter på materialer som ikke er gode nok, du møter på redskaper som er sløve, du får ikke prestert da og ... du møter litt veggen ... jeg sitter på mye kompetanse som bare smuldrer opp fordi at man fär de begrensingene man fär /.../ (Ellen)

Ellens utsagn uttrykker godt det generelle inntrykket i mange av utsagnene jeg fikk tilgang til via surveyundersøkelsen (i det frie kommentarfeltet). I tilfeller der alt av «rekvisita» for trearbeidspraksiser er nærmest ikke-eksisterende, kan praksisene gradvis forsvinne. Ellen velger heller å bruke eget klasserom når hun spikker med elevene.

- Aina - «rigger til så godt vi kan»

På besøk hos Aina får jeg observere syv elever som lager tresleiver. Aktiviteten skjer $i$ et slags allrom med to sløydbenker og noen vanlige pulter og sofa $i$ et hjørne.

I.../ når vi skal ha kunst og håndverk så må vi bare rigge til så godt vi kan, og når det er en treoppgave, så må vi jo hente de her hovelbenkene ut fra kjelleren og sette de her og så setter vi dem ned $i$ kjelleren igjen når vi er ferdige med de /.../ (Aina)

Aina opplever romlige utfordringer. I tillegg til mangelen på et spesialrom til trearbeid, har elevene lite utstyr slik at de må vente på tur og la redskapene gå «på omgang». Sløydbenkene må hentes fra kjelleren i perioder med trearbeid. Aina har likevel skapt et fungerende rom og «rigget opp» et provisorisk «sløydrom» for å bevare en lokal trearbeidstradisjon. 


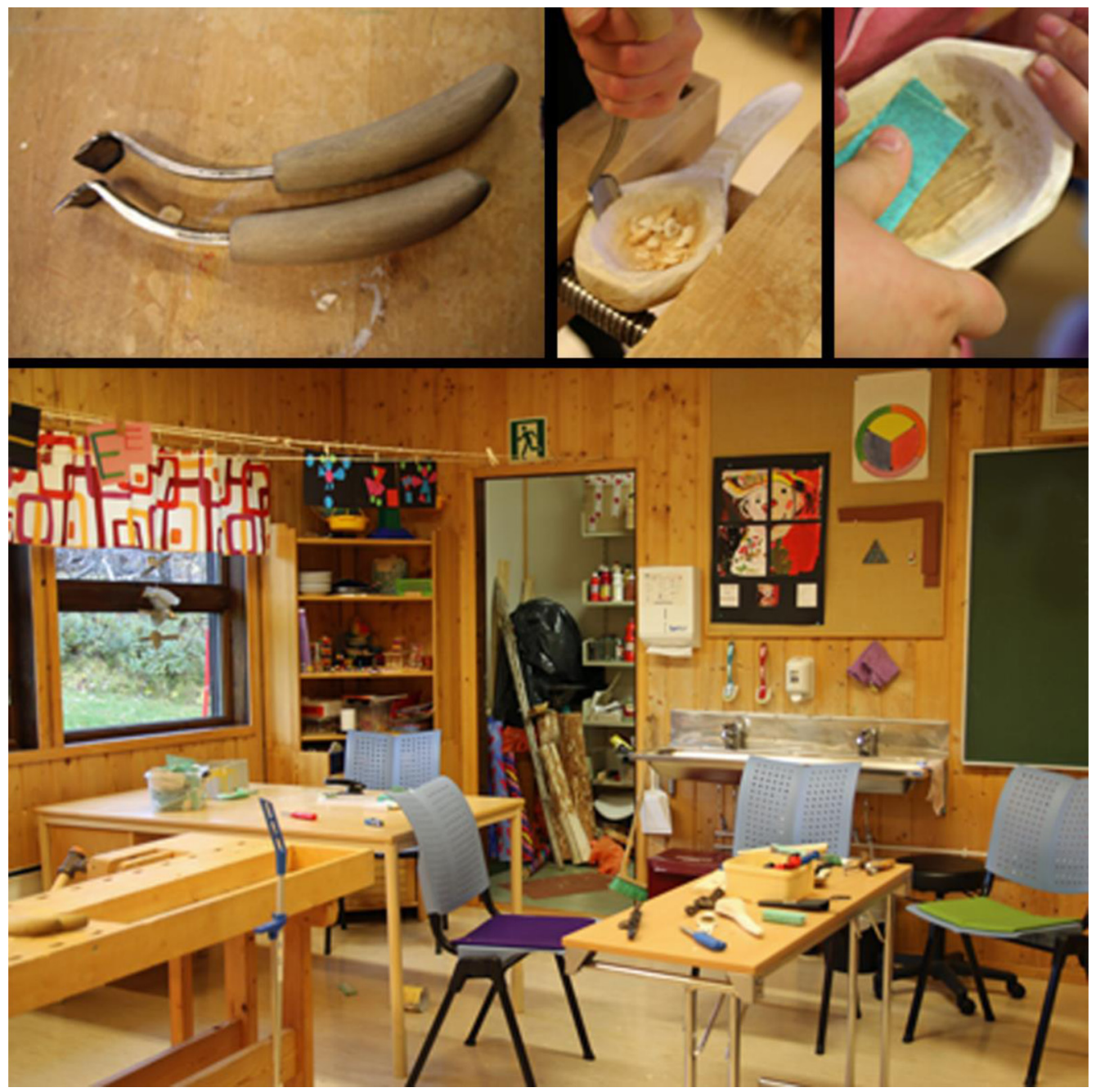

Bildecollage 2. «Allrommet» hos Aina.

- Mona - et rom for de voksne?

I trearbeidsrommet som vises i bildecollage 3 (hos Mona som i intervjusamtalen sa at hun har ingen kompetanse $\mathrm{i}$ eller interesse for kunst og håndverk/trearbeid) kan kjente elementer som sløydbenker og verktøyskap identifiseres. Det som likevel fanger oppmerksomheten, er at i nesten halve rommet, som ikke virker større enn 30-40 $\mathrm{m}^{2}$, er gulvet dekket med store kombinasjonsmaskiner.

/. . . det bør ikke vare noen flere her fordi det er kjempetrangt ... på mellomtrinnet er de noen og tjue, som skulle vart der inne, det blir kaos /.../ (Mona)

Flere av lærerne får hodepine mens de er i kunst- og håndverkslokalene:

/... . så vi på skolen kaller ... det kunst og håndverk-hodepine /.../ (Mona) 


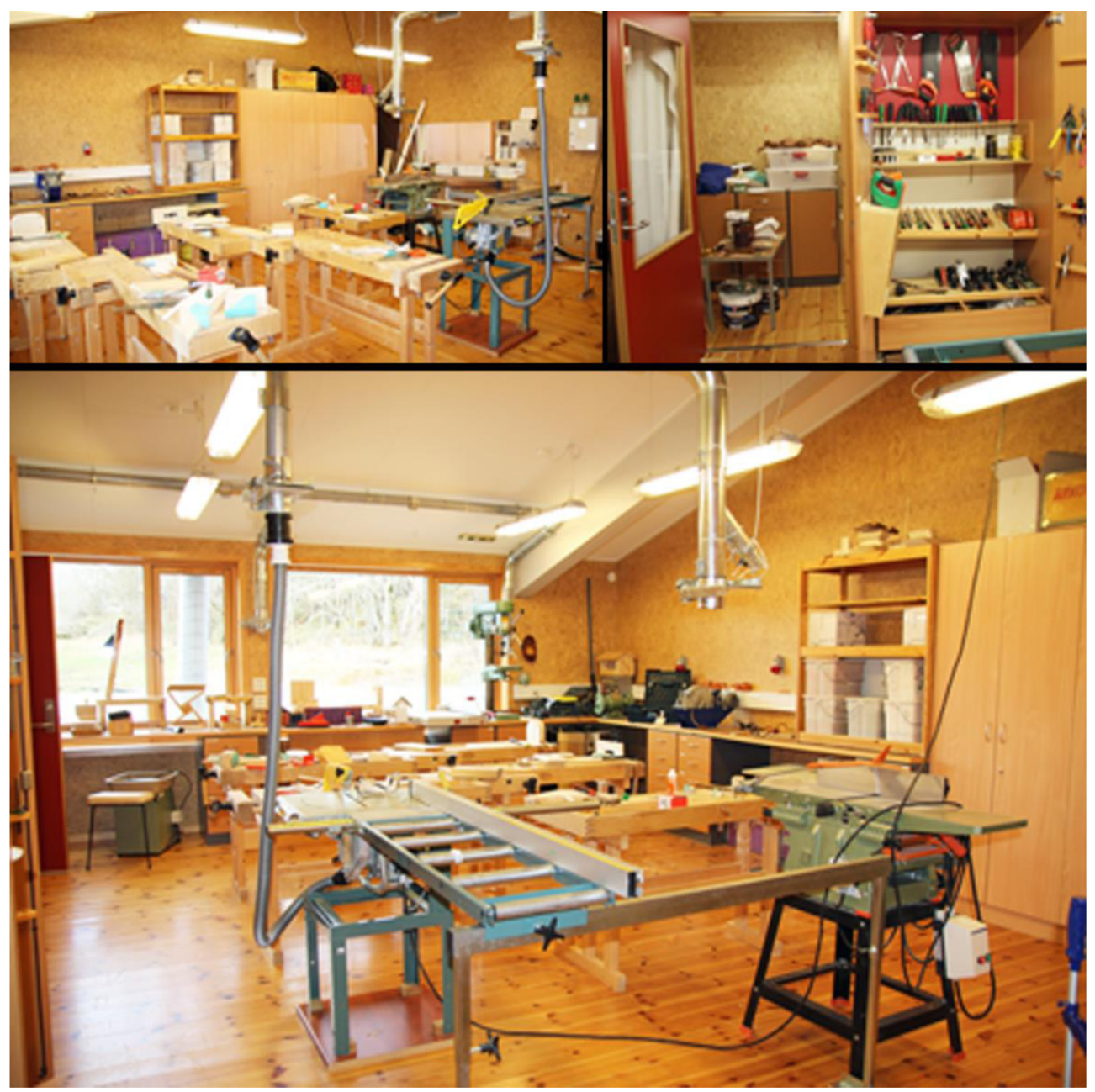

Bildecollage 3. Trearbeidsrommet hos Mona.

Rundt de fem små høvelbenkene er det vanskelig å finne gode arbeidsstillinger for barnekropper. I tillegg kan de store maskinene skape en ubevisst utrygghetsfølelse, en bekymring som gjennomsyrer atmosfæren i rommet. "Atmospheres are evidently what are experienced in bodily presence in relation to persons and things or in spaces» (Böhme 1993, s. 119). De store maskinene sier «fare», lærernes reaksjon på romopplevelsen «kunst og håndverkhodepine» - uttrykker situasjonens uholdbarhet i sin helhet.

- Ingvild - et rom full av «action»

Ingvild beskriver hvordan hun har organisert undervisningen slik at de samme elevene jobber to dager etter hverandre:

/... / den gruppa her hadde jo en økt $i$ går, hvor vi slapp à rydde opp ... så det er veldig effektivt ... det er ikke vits å gå ned for bare en halvtimes effektiv jobbing /. . . (Ingvild) 


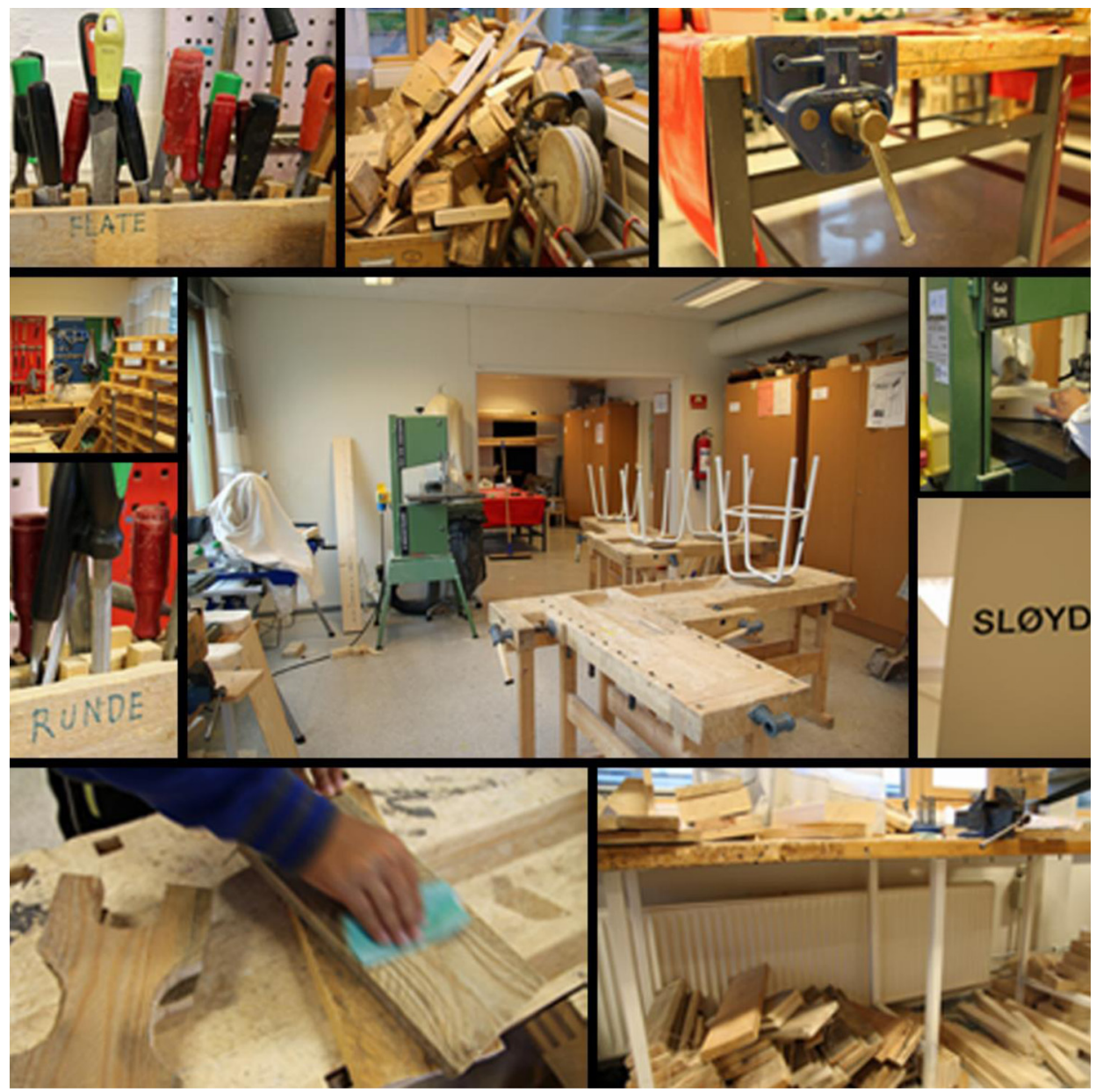

Bildecollage 4. Hos Ingvild - gamle paller byr på mange muligheter.

Selv om rammene i tid-rom (mange elever) for Ingvild virker utfordrende, har hun en form for selvbestemmelse over rommene som støtter opp under og muliggjør trearbeidspraksisen.

I mange av de situasjonene jeg fikk observere, oppfattet jeg elevene som veldig selvstyrte, slik var det også hos Ingvild. Rommet med høvelbenker, rasper, sager, driller og mengder av trematerialer innbyr elevene å handle på en viss måte. Høvelbenkene kan ses på som aktive aktanter (Latour, 2004) som byr på muligheten til å feste trearbeidsstykker i. De slitte grå trestykkene som ligger rundt i rommet, byr på ulike former for «action», som å bli satt sammen til en krakk.

Byggeklossen rom og materialiteter vitner om store forskjeller i forholdene i de utvalgte skolene. For at et trearbeidsrom skal kunne instruere elever på en god måte i deres arbeid, er kvaliteter i den sammenvevde interaksjonen der aktive aktanter (humans) elever og lærere, samt (non-humans) trematerialer, høvelbenker, hamrer, uthulingsjern, pussepapir, trepaller, sager osv. - deltar, avgjørende for resultatet. 


\section{Pauliina Maapalo}

\section{Integritet som byggekloss}

Erfaringer fra de åtte skolebesøkene kaster lys over betydningen av lærerens autonomi innen trearbeidspraksiser. Lærerne med autonomi og påvirkningskraft over romlige og faglige organiseringer, samt fordelingen av menneskelige ressurser, kan muliggjøre trearbeidspraksiser. For å forstå betydningen av begreper som autonomi, påvirkningskraft og bestemmelsesrett støtter jeg meg til Eriksens (2015a) tanker om profesjonell integritet. Eriksen sammenfører en forståelse av integritet som dyd (virtue) og forsikring (assurance to the public) og skaper en syntese. Begge disse møtes $\mathrm{i}$ et fortolkende syn på profesjonell integritet der en evaluerende vurderingspraksis vektlegges (Eriksen, 2015a, s. 14-15). Det som gjør at lærerne kan nyte godt av den autonomien de har i deler av sine praksiser, henger sammen med deres evne til å forsikre og dermed synliggjøre og kommunisere trearbeidspraksisens verdi overfor skoleledelse, kollegaer, foreldre og ikke minst elever (relateringer). Lærerne har tillit til å gjøre det som er moralsk rett selv om det noen ganger kan være i konflikt med retningslinjer. Dette kommer til syne for eksempel i lærernes kritikk, tolkning og bruk av læreplaner (sosio-politiske/ kulturelle-diskursive forhold):

/. . I så er min intensjon det her, å ikke miste fagets egenart fordi at du skal få for mye annet inn ... ikke innfor noe kunsthistorie $i$ skolen ... visuell kommunikasjon og ... [at]du skal bruke datamaskiner... jeg syns det er viktig at de får bruke hendene og får kjennskap til ulike materialer /.../ (Kristin)

Kristin mener at læreplanen inneholder altfor mange mål og områder slik at egenarten blir borte. Dette samstemmer med det Sømoe (2014) sier om at faget er blitt et tverrfaglig felt. Samtidig er det Kristins faglig-profesjonelle integritet som gjør at hun velger å fokusere på at elevene får bruke hendene.

Integritet forutsetter kompetanse og kommer til syne i lærernes praksiser, blant annet der lærerne iherdig holder trearbeidspraksiser i live med den overbevisningen at de har en verdi, tross stramme materielle-økonomiske forhold.

\section{Elevengasjement og lererdedikasjon $i$ samspill som byggekloss}

En av de mest iøynefallende opplevelsene i forbindelse med skolebesøkene var elevenes iver i møte med trearbeid.

\footnotetext{
I. . . / de er liksom ivrige på å komme i gang . . jeg har stått mange år i klasserommet og hjulpet ungene til å holde ut arbeidsøkten, altså i tradisjonelle fag ... og der opplevde jeg ofte at det kan vare et slit og tungt og vanskelig à vaere $i$ slike mentale prosesser over lang tid... men her når vi jobber med hender, jobber med noe fysisk, så opplever jeg at den utholdenheten deres er helt annerledes ... og det er ofte et slit å få dem til å ta en pause... her måjeg ofte dytte de ut for à ta en pause ... det jeg tror ... det er noe med det her taktile altså som er så sentralt hos oss menneskene, som de møter for lite ut av, eller tenker jeg ... i hvert fall i skolen /. . . (Terje)
}

Det er noe materialet tre kan by på, som får elevene til å bli så engasjert at de holder ut og ikke vil ta pauser $\mathrm{i}$ arbeidet. 
I tillegg til tre som materiale, er det den engasjerte læreren som med sin integritet og omsorg opprettholder og viderefører trearbeidspraksiser. Utsagnene fra Pål beskriver godt dette:

I. . . jeg har en ... fjellseter ... der jeg henter einer fra ... men den må jo tas ned ... kappes på sommeren, og så må det tørke til neste år, så kan vi bruke det ... er en krevende prosess [...] så ... det vi har hatt mest nytte av, det er den lille skogen vår . . . . ./ (Pål)

Utsagnet ovenfor beskriver hvordan læreren er dedikert til praksisen. Idet jeg bruker begrepet dedikasjon og den dedikerte læreren henviser jeg til Eriksen (2015b, s. 1) sin karakterisering av profesjonelle dyder: «Professional virtue requires that role holders care about the ends of their work. Care is understood in terms of an investement of the self». Pål investerer seg selv og bryr seg om elevenes praksis ved å sørge for materialtilgangen i økonomisk vanskelige tider gjennom kreative og tidskrevende løsninger.

For læreren er prosjektet for praksisen noe annet enn for elevene. Kemmis et al. (2014) beskriver prosjektet til læreren som noe som utgjør en conjoint whole der det læreren sier, gjør og relaterer, framstår som en samlet helhet som samtidig åpner et semantisk rom, et fysisk rom, og et sosialt rom i det intersubjektive rommet læreren og elevene deler. Fra elevenes perspektiv skjer alt som en enkeltstående, helhetlig, fenomenologisk sammensatt praksisarkitektur (Kemmis et al., 2014, s. 206). Slik jeg har fått observere elevene, virker det som om de klarer å gå inn i en slags tilstand av flyt (flow), en tilstand med så intens konsentrasjon at de mister den bevisste selvoppmerksomheten og opplevelsen av kronologisk tid (Csikszentmilhalyi, 2002, s. 71). Det er noe med trematerialenes uendelig mange intensivt varierende kvaliteter (Deleuze \& Guattari, 2013, s. 37): tyngder, lukter, variasjoner i fiberretninger, farger og mønstre som inviterer til ulike former for motstand, sanselig engasjering og tilstander av flyt. I en tilstand av flyt vil de utfordrende materielt-økonomiske forholdene i praksisarkitekturene ikke forstyrre elevene. Deres prosjekt i praksisen er å lage en fysisk ting, et produkt. For læreren, som jobber didaktisk og sløydpedagogisk, er den tilsynelatende helhetlige situasjonen mye mer kompleks. Idet eleven opplever flyt, kan læreren oppleve mangelen på tid, skissere kreative løsninger for anskaffelse av materialer (som Pål), tenke på forhandlinger av menneskelige ressurser, foreldremøter, lønnsforhandlinger og neste semester. En dedikert lærer vil, midt opp i alt dette, klare å identifisere og bry seg om elevenes praksisprosjekt - det å få til et produkt - og kjempe for at det finnes trematerialer tilgjengelig. I Påls tilfelle handler det om materialer med helt unike kvaliteter.

\section{Tradisjon som byggekloss}

Byggeklossen tradisjon ble gradvis mer og mer fremtredende idet jeg fikk møte rommene, elevene og lærerne i sine praksiser. I teorien om praksisarkitekturer beskriver Kemmis et al. (2014, s. 31) praksistradisjoner som noe som innkapsler historien av hendelsene i praksisen, som noe som lar den bli reprodusert og fungere som et slags kollektivt minne/hukommelse av praksisen. I denne studien var det først 
og fremst i byggeklossen rom og materialitet at de fleste tegnene på trearbeidstradisjoner så ut til å være lagret, bevart og videreført.

Hos Kristin var det gamle «sløydrommet» en aktant, som fungerte som en bærer av tradisjoner og instruerte henne med å videreføre praksisen. I skapene kunne man finne gamle arbeider fra tidligere elever, som igjen ble brukt som inspirasjon til dagens elever. I trearbeidsrommet til Pål er det synlige minner fra gamle håndverkspraksiser langs veggene. I Ainas hjembygd lever bygdas tresleivtradisjon videre blant hennes elever. Redskapene, uthulingsjernene er laget av bestefaren til en av elevene og trematerialet, en selje bak skolen, ble felt av vaktmesteren.

Tradisjoner innbakt i de sosio-politiske byggeklossene kommer til syne i blant annet relasjonenes betydning. Pål sin kompetanse og interesse bygger på lange tradisjoner innen trearbeid, kunst og håndverk og lærerprofesjoner i familien. Kristin har ikke interesser utenom egen praksis, men hun har en sterk tilknytning til tidligere sløydlærere, andre skoler i bygda med levende trearbeidstradisjoner samt en egenerfart «tresløydpraksis» fra tiden hun var elev i skolen og lærerstudent. Mona, som ikke oppviser interesse for kunst- og håndverksfaget, mangler nettopp tradisjonen. Kanskje har hun ingen tradisjonsbærer i familien som kunne gitt henne en interesse som kunne fungert som drivkraft i hennes lærervirke.

Tradisjon i all dens ulike former ser ut til å være en gjennomgående, underliggende byggekloss, eller kanskje selve fundamentet for trearbeidspraksiser.

\section{Drøfting - byggeklosser som muliggjør og hindrer trearbeid i grunnskolen}

I denne artikkelen har jeg latt meg lede av forskningsspørsmålet «Hvordan kan konturene av byggeklosser $i$ praksisarkitekturer for arbeid med materialet tre $i$ barneskolen tegnes opp og kritisk diskuteres gjennom analyse av et empirisk materiale bestående av spørreundersøkelse og skolebesøk?». Jeg har gjennom analysen konstruert byggeklosser i en praksisarkitektur; byggeklosser som muliggjør eller hindrer/begrenser trearbeidspraksiser i barneskoler. Disse byggeklossene har jeg definert som kompetanse, rom og materialitet, integritet, elevengasjement og larerdedikasjon i samspill og tradisjon. Ved skolebesøkene har jeg sett at i en dynamisk bevegelse seg imellom påvirker alle disse byggeklossene den praksisarkitektur som muliggjør og begrenser arbeid med tre i norsk barneskole.

I et større utdanningspolitisk perspektiv blir kompetanse nærmest utelukkende sett på som et positivt ladet begrep. Et av de sentrale funnene i min undersøkelse angående lærernes kompetanse samstemmer med resultater fra Skolefagsundersøkelsen 2011 (Espeland et al., 2013). I denne studien kom det fram at lærere med lite kompetanse underviser samlet sett mest innen trematerialer, men med minst timetall per lærer. Dette kan tolkes som at undervisningen i tre først og fremst gjøres av klasselærere, ikke av faglærere i kunst og håndverk.

Studien avdekker store forskjeller i nivået av formell kompetanse innen kunst og håndverk og spesielt innen trematerialer. Generelt sett virker det som om «kunst- og håndverk-studiepoengene» inneholder svært lite trearbeid og at det er få lærere som har formell kompetanse innen trematerialer. Samtidig er det noen som ikke får brukt 
den formelle kompetansen sin fordi byggeklossen rom og materialitet hindrer dette, noe som igjen er avhengig av sosio-politiske forhold, slik som hvilke fag som prioriteres. Skoleeiernes prioriteringer, som kanskje styres av politiske beslutningsprosesser, kan påvirke for eksempel hvorvidt det i det hele tatt finnes et brukbart trearbeidsrom i en skole. I Skolefagsundersøkelsen 2011 er det også nevnt at «flere lærere poengterer at mangel på kompetanse og utstyr er med på å vri faget over til å bli et rent kunst- og kunstteorifag i skolen» (Espeland et al., 2013, s.77).

Min studie peker $\mathrm{i}$ den retning at uformell kompetanse og interesse for arbeid med trematerialer har stor betydning for at det i det hele tatt fortsatt finnes trearbeid i barneskoler. Kompetansens betydning som byggekloss innen trearbeidspraksiser i barneskoler, er uansett sentral. En lærer med formell og/eller uformell kompetanse vil være i stand til å identifisere hva som må til for at trearbeidsrommet fungerer bra, noe som igjen vil muliggjøre en trearbeidspraksis i skolen. På denne måten skaper interaksjonen mellom praksisarkitekturens byggekloss kompetanse med byggeklossen rom og materialitet et selvforsterkende samspill.

Byggeklossene elevengasjement og lererdedikasjon $i$ samspill og tradisjon skaper et slags bærende skjelett i praksisarkitekturen for trearbeidspraksiser. Elevenes engasjement (som vekkes av materialet tre) vekker en respons hos læreren i og med at læreren ser at arbeidet betyr noe for elevene, og samtidig vekker lærerens dedikasjon (aktualisert for eksempel gjennom arbeid som anskaffelse av materialer) en respons hos elevene. Det er tre som materiale som «limer» praksisen sammen. Byggeklossen rom og materialiteter er i sentrum i trearbeidspraksiser. Et godt trearbeidsrom med velfungerende utstyr og gode, varierte trematerialer er aktive aktanter (Latour, 2004, s. 75) som instruerer og hjelper elevene i deres praksiser.

Kompleksiteten og avhengighetsforholdet mellom ulike praksiser knyttet til trearbeidspraksiser i skolen blir godt belyst ved begrepet praksisøkologier (Kemmis et al., 2014, s. 43-53). En forandring i en praksis, som tilgang til rom og materialer, vil påvirke en annen praksis, som for eksempel elevenes læringspraksis. Hvis man ønsker en forandring et sted, må alle praksisene som er nært knyttet til hverandre, forandres på. Med denne forståelsen av praksisøkologier vil det faktumet at det femte største skolefaget i norsk grunnskole- kunst og håndverk - ikke er et obligatorisk fag $\mathrm{i}$ lærerutdanningen, sannsynligvis giøre mange elevers undervisningspraksiser innen trearbeid meget usikre. En forandring kan virke nødvendig, og lærerutdanningen er et interessant ledd å se mer på i videre forskning. Praksisarkitekturenes byggeklosser som fortsatt holder konturene av trearbeid i norsk barneskole sammen, er sårbare, tilfeldige og skjøre.

I denne undersøkelsen tegnes det opp kun en liten «bit» av virkeligheten fra noen utvalgte trearbeidspraksiser akkurat nå. Samtidig samstemmer undersøkelsen godt med tidligere forskning og undersøkelser. Den refleksive forskerposisjonen jeg har forsøkt å innta, har vært nødvendig fordi jeg selv som skolebesøkende forsker har vært en del av det jeg har forsket på. Dette kan sees på som en trussel i forhold til troverdigheten av studien, men også som en nødvendighet når hensikten har vært å skape en nærhet til praksiser. 
Mitt håp er at denne undersøkelsen og analysen kan bidra til å gi økt innsikt i trearbeidspraksiser og de utfordringene praktikerne, elevene og lærerne møter i disse. Studien kan invitere til kritisk refleksjon rundt forhold som muliggiør eller hindrer trearbeidspraksiser og dermed «åpne et rom» for diskusjon - noe som naturligvis også vil handle om spørsmål knyttet til hvorvidt trearbeidspraksiser i det hele tatt trengs eller hvilken verdi arbeidet med tre som materiale i skolen kan ha. Videre, $\mathrm{i}$ forskningsøyemed, er det interessant å se nærmere på hva elever faktisk lager i tre og hvordan lærerne tenker rundt trearbeidsprosesser, for å få et enda mer stabilt bilde av den praksisarkitektur som omkranser arbeid med materialet tre i barneskolen.

\section{Biography}

Pauliina Maapalo er kunst- og håndverkslærer og lærerutdanner ved Nord universitet i Norge, avdeling Nesna, der hun for tiden er i en stipendiatstilling. Hun er spesielt opptatt av utviklingen av læring/undervisning med fokus på materialet tre og spørsmål knyttet til økologi/bærekraft.

\section{Referanser}

Autio, O. (1997). Oppilaiden teknisten valmiuksien kehittyminen peruskoulussa. Tytöt ja pojat samansisältöisen käsityön opetuksen kokeilussa [Student's development in technical abilities in Finnish comprehensive school. Boys and girls in an experiment of shared craft education]. (Doktorgradsavhandling), Helsinki: Helsingin yliopiston opettajankoulutuslaitos.

Bennett, J. (2010). Vibrant Matter. Durham and London: Duke University Press.

Berntsen, D.O. (2014, 6. november). Få høvelbenken tilbake i skolen. Morgenbladet. Hentet fra https:// morgenbladet.no/ideer/2014/fa_hovelbenken_tilbake_i_skolen

Borg, K. (2001). Slöjdämnet, intryck - uttryck - avtryck. (Doktorgradsavhandling), Institutionen för beteendevetenskap, Linköping: Linköpings universitet.

Braidotti, R. (2013). The Posthuman. Cambridge: Polity Press.

Brænne, K. (2009). Mellom ord og handling. Om verdsetjing $i$ kunst og handverksfaget. (Doktorgradsavhandling), Oslo: Arkitektur- og designhøgskolen i Oslo.

Brænne, K. (2011). Vedlikehald av ein konstruert kontrovers. Formakademisk, 4(2), 95-108.

Böhme, G. (1993). Atmosphere as the fundamental concept of a new aesthetics. Thesis Eleven, 36, $113-126$.

Csikszentmihalyi, M. (2002). Flow. London: Rider.

Deleuze, G. \& Guattari, F. (2013). A Thousand Plateaus. London: Bloomsbury.

Digranes, I. (2009). Den kulturelle skolesekken. Narratives and myths of educational practice in DKS projects within the subject art and craft (Doktorgradsavhandling). Hentet fra https://brage.bibsys.no/xmlui/bitstream/ handle/11250/93038/38_Digranes_avhandling.pdf?sequence=1\&isAllowed=y

Dunin-Woyseth, H. \& Michl, J. (2001). Towards a disciplinary identity of the making professions: an introduction. In H. Dunin-Woyseth \& J. Michl (red.), Towards a disciplinary identity of the making professions. The Oslo Millenium Reader (s. 1-20). Oslo: Oslo School of Architecture.

Eriksen, A. (2015a). What is professional integrity? Etikk i praksis. Nordic fournal for Applied Ethics, 9(2), 3-17. doi: http://dx.doi.org/10.5324/eip.v9i2.1836

Eriksen, A. (2015b). Should Eudaimonia Structure Professional Virtue? Fournal of Philosophy of Education. doi: http://dx.doi.org/10.1111/1467-9752.12162

Espeland, M., Arnesen, T.E., Grønsdal, I.A., Holthe, A., Sømoe, K., Wergedahl, H. \& Aadland, H. (2013). Skolefagsundersøkelsen 2011. Hentet fra https://brage.bibsys.no/xmlui/handle/11250/152148

Fauske, L.B. (2016). Reforhandling av kunnskapsgrunnlag. Forskning og fagutvikling med utspring i designdidaktikk. Techne Series A, 23(2), 50-68.

Frohagen, J. (2016). At kunna saga rakt. Om manuell utbildning i skolämnet slöjd. Techne Series A, 23(2), 16-33.

Gulliksen, M. (2006). Constructing a Formbild. (Doktorgradsavhandling). Hentet fra https://dspace01.hit.no/ bitstream/handle/2282/1319/Publisert_avhandling.pdf?...1

Hansen, B.H. (2015). Trearbeid og treverksteder i grunnskolen: Skolelederes verdsetting og prioritering sett opp mot tradisjon og fornyelse i faget Kunst og håndverk. (Mastergradsavhandling). Hentet fra https://oda.hio.no/jspui/ handle/10642/2712 
Hartvik, J. (2013). Det planlagda og det som viser sig: Klasslärerstuderandes syn på undervisning $i$ teknisk slöjd. (Doktorgradsavhandling), Åbo: Pedagogiska fakulteten, Åbo akademis förlag.

Hilmola. A. (2012). The sloyd teachers' working methods in Finnish comprehensive schools. Procedia - Social and Behavioral Sciences, 45, 41-53.

Høiby, N. (2014). Trearbeid - mellom lereplan og praksis. (Mastergradsavhandling). Hentet fra https://oda.hio. no/jspui/bitstream/10642/2092/2/Hoiby_Nina.pdf

Illum, B. (2004). Det manuella håndvcerksmassige og laring - processens dialog. (Doktorgradsavhandling), København: Danmarks pedagogiska universitet.

Iversen, V. (2016). Få høvelbenken tilbake i skolen! Agderposten. Hentet fra http://www.agderposten.no/ meninger/fa-hovelbenken-tilbake-i-skolen-1.1495191

Johansson, M. (1998). Dåtid - Nutid - Samtid - Framtid. Slöjd utifrån ett materiellt och immateriellt angreppssätt. I L. Lindfors, J. Peltonen \& M. Porko (red.), Slöjdkompetens i nordisk kultur. B:4. Techne Serien (s. 114-122). Vasa: NordFO.

Johansson, M. (2002). Slöjdpraktik $i$ skolan hand, tanke, kommunikation och andra medierande redskap. (Doktorgradsavhandling), Göteborg: Acta Universitatis Gothoburgensis.

Kemmis, S. \& Grootenboer, P. (2008). Situating praxis in practice: Practice architectures and the cultural, social and material conditions for practice. I S. Kemmis \& T.J. Smith (red.), Enabling praxis: Challenges for education (s. 37-62). Rotterdam: Sense.

Kemmis, S., Wilkinson, J., Edwards-Groves, C., Hardy, I., Grootenboer, P., \& Bristol, L. (2014). Changing Practices, Changing Education. Singapore: Springer.

Kjosavik, S. (1998). Fra ferdighetsfag til forming: utvikling fra tegning, sløyd og håndarbeid til forming sett $i$ et lereplanhistorisk perspektiv. (Doktorgradsavhandling), Oslo: Det utdanningsvitenskapelige fakultet, Universitetet i Oslo.

Kjosavik, S. (2001). Sløjdens utvikling i Norge 1860-1997. I C. Nygren-Landgärds \& J. Peltonen (red.), Visioner om slöjd och slöjdpedagogikk. Forskning $i$ slöjdpedagogikk och slöjdvitenskap B:10/2001. Techne Serien (s. 166-193). Vasa: NordFo.

Knudsen, R. (2015) Et fag under avvikling? Utdanning, 20, 46.

Latour, B. (1996). On actor-network theory. A few clarifications plus more than a few complications. Soziale Welt, 47(4), 369-381.

Latour, B. (2004). Politics Of Nature - How to Bring the Sciences into Democracy. Cambridge \& London: Harvard University Press.

Latour, B. (2005). Reassembling the Social. An Introduction to Actor-Network-Theory. Oxford: Oxford University Press.

Lindfors, L. (1999). Slöjdpedagogikens grundfrågor. Nordisk pedagogik, 19(2) 2, 78-90.

Lutnæs, E. (2011). Standpunktvurdering i grunnskolefaget Kunst og håndverk. (Doktorgradsavhandling), Oslo: Arkitektur- og designhøgskolen i Oslo.

Mäkelä, E. (2011). Slöjd som berättelse - om skolungdom och estetiska perspektiv. (Doktorgradsavhandling), Umeå: Institutionen för estetiska ämnen, Umeå universitet.

Nielsen, L.M. (2008). Designdidaktisk forskning i utvikling - en forskningsoversikt 1997-2007. FORMakademisk, 1(1), 19-27.

Nygren-Landgärds, C. (2000). Educational and teaching ideologies in sloyd teacher education. (Doktorgradsavhandling), Åbo: Åbo Akademi University Press.

Opstad, K.D. (2013). Vi trenger ikke kunst og håndverk for å bli lærere. FORM, 5, $22-23$.

Peltonen, J. (1999). Slöjdkultur och slöjdpedagogik. En vetenskapsteoretisk betraktelse. Nordisk pedagogik, 19(2), 67-77.

Pink, S. (2015). Doing Sensory Ethnography (2. Ed.). SAGE Publications: London.

Postholm, M. B. (2010). Kvalitativ metode: en innføring med fokus på fenomenologi, etnografi og kasusstudier. Oslo: Universitetsforlaget.

Sandvik, H. (2015). Frå hand til munn? Bergens Tidende. Hentet fra http://www.bt.no/btmeninger/kommentar/ sandvik/Fra-hand-til-munn-3274689.html

Schatzki, T. R. (2012). A primer on practices. I J. Higgs, R. Barnett, S. Billett, M. Hutchings \& F. Trede (red.), Practice based education (pp. 13-26). Rotterdam: Sense Publishers.

Skolverket. (2011). Kursplan $i$ slöjd för grundskolan. Hentet fra http://www.skolverket.se/om-skolverket/ publikationer/visa-enskild-publikation?_xurl_=http $\% 3 \mathrm{~A} \% 2 \mathrm{~F} \% 2 \mathrm{Fwww} 5$. skolverket.se $\% 2 \mathrm{Fwtpub} \% 2 \mathrm{Fws} \%$ 2 Fskolbok\%2Fwpubext $\% 2$ Ftrycksak\%2FRecord\%3Fk $=2650$

Sømoe, K. (2013). Kunst og håndverk - fag eller tverrfaglig felt? FORMakademisk, 6(3), 1-15.

Thorsnes, T. (2012). Tresløydhistorie - Fra hendig til unyttig? Oslo: Abstrakt forlag. 


\section{Pauliina Maapalo}

Utbildningsstyrelsen. (2014). Grunderna för läroplanen. Hentet fra http:/www.oph.fi/lp2016/grunderna_for_ laroplanen

Utdanningsdirektoratet. (2006). Lcereplan i kunst og håndverk. Hentet fra http://www.udir.no/k106/KHV1-01/ Hele/Kompetansemaal/etter-4.-arstrinn

Østern, A.-L. (2016). Responssløyfer i veiledningsprosesser - en studie av muligheter knyttet til en teori om praksisarkitekturer i utdanning. I A.-L. Østern \& G. Engvik (red.), Veiledningspraksiser i bevegelse (s. 19-44). Bergen: Fagbokforlaget. 